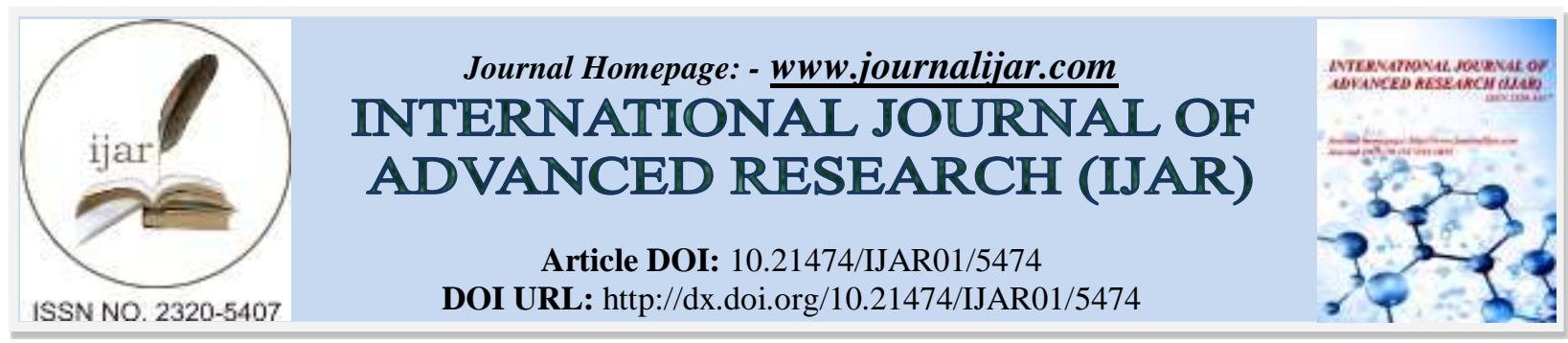

RESEARCH ARTICLE

\title{
RECONSTRUCTION OF SHIGHAT TAKLIK TALAK AS A REASON FOR DIVORCE IN ISLAMIC COURT OF RELIGION TO MAKE A JUSTICE-BASED JUDGE'S DECISION.
}

\author{
Ichwan Qomari, Gunarto, Akhmad Khisni and Anis Mashdurohatun. \\ Faculty Of Law, Universitas Sultan Agung Semarang, Indonesia.
}

\section{Manuscript Info}

Manuscript History

Received: 19 July 2017

Final Accepted: 21 August 2017

Published: September 2017

Key words:-

Reconstruction, Shighat Taklik Talak, Divorce, Islamic Court of Religion, Justice.

\begin{abstract}
The purpose of this study was to find the reconstruction of shighat taklik talak as the reason for divorce in the judge's judgment based on the value of justice. The paradigm used in this research is constructivist paradigm. The research's approach method is empirical juridical. research data source used in this research is primary data and secondary data. Data were analyzed descriptively and analitically. The findings of this study are unilateral Promises in safeguarding the rights of the wife, therefore if the person refuses not to read and sign according to the Permenag no. 11 Article 24 paragraph (2), the wife can file a case to the Religious Court in order to make Sighat Taklik Talak. Which can be used as a divorce reasons only the wife can use, resulting in a verdict of Divorce called Talak Khul'i by the judge. Reconstruction of Sighat Taklik should be formulated as a marriage agreement as article 45 and article 46 of KHI jo. Article 11 of Regulation no. 2 year 1990. So that there is a balance of rights between husband and wife.
\end{abstract}

Copy Right, IJAR, 2017,. All rights reserved.

\section{Introduction:-}

One of the principles of marriage prescribed is marriage for forever which is covered by compassion, mutual love. ${ }^{1}$ $\mathrm{n}$ the Qur'an (5: 21) it is stated that marriage is one form of "mitsaaqan ghalida". In Islamic Law, Marriage has become one of the most important things to be done (based on syari'a law), ${ }^{2}$ advisable because it is not only required by the prophet as dictated by the gods but also to avoid unnecessary suspicion of adultery; ${ }^{3}$ The association of married life is conceptualized in a husband and wife relationship with peaceful atmosphere, full of love and affection (sakinah, mawaddah, and rahmah). ${ }^{4}$

\footnotetext{
${ }^{1}$ Kamal Muchtar, Asas-asas Hukum Islam tentang Perkawinan, (Jakarta: Bulan Bintang, 1974), p. 144.

${ }^{2}$ Wahbah Az-Zuhaili, Fiqih Islam Wa Adillatuhu, Jilid 9, Penerjemah: Abdul Hayyie al-Kattani, dkk., Depok: Gema Insani, 2011, p. 40.

${ }^{3}$ Sayyid Sabiq, Fiqih Sunnah, Jilid 2, Penerjemah: Nor Hasanuddin, dkk., Jakarta: Pena Pundi Aksara, 2006, p. 481

${ }^{4}$ Sulaeman Abdullah, Gunarto, Akhmad Khisni, Reconstruction of courts authority in children foster rights dispute due to the differences based on the value of Islamic law justice, International Journal of Multidisciplinary Research and Development Online ISSN: 2349-4182, Print ISSN: 2349-5979, Impact Factor: RJIF 5.72 Volume 4; Issue 7; July 2017; Page No. 225-231, also p. 255
} 
On the other hand, it is indeed very good for human life if it can be kept so on. However, when a problem occur that can not be solved except by divorce, it will also result in a dilemma, because on one hand neither religion nor legislation does not allow divorce, but the individual demands for divorce is hard to avoid.

Sayyid Sabiq in his book Fiqh al-Sunnah states that Islam gives the right of divorce only to men. Because men are the one who have the responsibility to perpetuate wedding, so that if they remarry will cost more. They also have the responsibility of giving a living and the gift of divorce to his wife. Sayyid Sabiq further adds that men have a more patient mind and character to deal with his wife's temperament, so that when something happens with his wife, he can still think calmly and does not quickly divorce her, while women tends to get angry and hasty. ${ }^{5}$

The material and psychological reasons given by Sayyid Sabiq above are quite plausible, but that does not mean that there are no weaknesses. The above reasons are very gender and monolithic bias (from husband to wife). Not all husbands have good intentions as stated above, meaning that there are many husbands that does not want to keep the household stood still and many more who can not think rationally and patiently.

Therefore, it is necessary to rethink the conceptual construction of talak and its implementation. In that very framework, are the thought of the Indonesian scholars who consider it necessary and recommended for a husband after the marriage ceremony to be subjected to sighat taklik talak so that the husbands should treat their wife well, also in an effort to give the wife the right to release the marriage because their husband violates the promise of taklik talak Pronounced at the time of the marriage contract.

Taklik talak as spoken after the marriage contract is a unilateral legal action (eenmijdeg) where the husband pronounces a promise relating to his own circumstances. That he will carry out his duties as husband as best he can and if he can not perform his duty even acting arbitrarily against his wife, then when the wife that does not accept it can issue a complain to the Religious Court by paying iwald can submit a divorce.

Thus the substance of taklik talak can be seen from two aspects namely as a marriage agreement and as a reason for divorce. This is as contained in the Compilation of Islamic Laws 45 and 46, in detail as a marriage agreement, while chapters 51 and 116 letter $\mathrm{G}$ as reasons for divorce.

Various problems arise regarding shighat taklik talak based on what has been drawn up by the Minister of Religion, it is necessary to reconstruct that based on the values of justice. So that in implementing the agreement in accordance with the provisions of the law of agreement without intervention from other parties. This research was conducted to provide answers to the problem of taklik talak formula contained in the marriage book certificate which until now is still applied that is about how reconstruction of sighat taklik talak as reason divorce in Justice Court based on the value of justice?

\section{Method of Research:-}

The paradigm used in this research is constructivist paradigm. Constructivist paradigm is the paradigm that is almost the antithesis of understanding that lays its observation and objectivity in finding a reality or knowledge. It regards the social science paradigm as a systemic analysis of the socially meaningful action through direct observation and detailed on the relevant social actors create and maintain or manage their social world.. ${ }^{6}$

Method of approach used in this study is non-doctrinaire legal research methods, namely to understand and examine the law in its social context because it focuses more on issues concerning the operation of law in society. ${ }^{7}$ Research specification used is descriptive analytical that is to describe about phenomenon that exist in environment according to research method. ${ }^{8}$ The research was conducted by taking the location in Wonosobo and Kendal Regency based on purposive non random sampling.

\footnotetext{
${ }^{5}$ Sayyid Sabiq, Fiqhu al-Sunnah, Juz II, (Beirut : Dar al-Fikr), p. 502.

${ }^{6}$ Dedy N. Hidayat, Paradigma dan Metodologi Penelitian Sosial Empirik Klasik, (Jakarta : Departemen Ilmu Komunikasi FISIP Universitas Indonesia, 2003), p. 3.

${ }^{7}$ George Ritzer, Sosiologi Ilmu Pengetahuan Berparadigma Ganda, (Jakarta: Rajawali Press, 1992), p. 4.

${ }^{8}$ I.S. Susanto, Kriminologi, (Semarang: Fakultas Hukum Universitas Diponegoro, 1990), p. 15.
} 
In this research data source used is primary data and secondary data. The samples in this study using purposive nonrandom sampling (sampling aims), data collection is done through: observation, literature study, interview. ${ }^{9}$

The data obtained are then presented in a systematic, logical and rational form of description. The data that have been obtained then analyzed descriptively qualitative. ${ }^{10}$

\section{Research Result and Discussion:- \\ Definition of Taklik Talak.}

The phrase taklik talak etymologically comes from two syllables, the word taklik and the word talak. The word taklik itself is a mashdar form of the word 'allaqa - yu'alliqu - ta'liiqan which means to hang something with something or make it depend on something. The Scholars give the definition of taklik as :

ربط حصول مضمون جملة بحصول مضمون جملة أخرى وتكون الجملأة الأولى جملة الجزاء و الثانية جملة الثرط

"Depending on the result of the sum of content called jaza '(result) with the other amount of content named Syara'.,"11

While the word talak comes from the word thallaqa - yuthalliqu-thallaqan which means leaving, separating, or releasing the bond. ${ }^{12}$ Abdurrahman al-Jaziri in his book al-Fiqh 'ala al-Madzahib al-Arba'ah, says that the notion of divorce is :

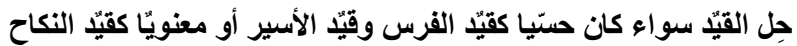

"Releasing bonds, either sensitively (intrinsically) such as releasing a horse or prisoner, as well as meaningfully giving up marriage." 13

The taklik talak in terminology as proposed by Wahbah Zuhaily is

ما رتب وقوعه على حصول أمر في المستقبل بأداة من أدوات الثرط أى التطليق مثل إن و إذا ومتى ولو ونحوها كأن يقول الرجل لزوجته وإن دخلت

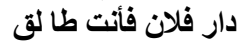

"A series of statements proving possible in the future by using the words of condition, as if, when, at any time, etc., as the husband said to his wife (if you enter the house fulan, then you had been "Talak"ed)". ${ }^{14}$

While Sayyid Sabiq in Fiqh Sunnah gives the definition of taklik talak with "

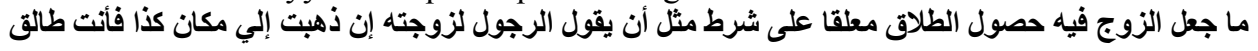

"Something that makes a husband drop a divorce according to a condition, such as the husband's words (if you go somewhere, then you had been given a talak). ${ }^{15}$

Then in the dictionary of fiqh term mentioned that taklik talak is decided at the fall on a certain thing, means the divorce will fall when this certain thing happened. For example if a husband says to his wife "You are given a talak if I do not give you shopping fund within three months", then if the husband is even three months does not provide for his wife, then the talak fell. ${ }^{16}$

From some of the above opinions can then be formulated that taklik talak is a series of divorce statement spoken by the husband, where the statement depend on a condition that proved possible in the future.

While the notion of taklik talak as practiced in Indonesia, has a difference with the notion of taklik talak available in the book of fiqh. As mentioned in the Compilation of Islamic Law, the notion of taklik talak is the agreement of the prospective bridegroom after the marriage certificate contained in the deed of marriage in the form of a promise of divorce that depends on a certain circumstance that may occur in the future. ${ }^{17}$ This is then in Islamic law which is practiced in Indonesia known as marriage agreement. Compilation of Islamic Law as one of the rules of Islamic law

${ }^{9}$ Burban Ashofa, Metode Penelitian Hukum, (Jakarta: Rineka Cipta, 2007), p. 95.

${ }^{10}$ I.S. Susanto, Kriminologi.... p. 51.

${ }^{11}$ Mahmud Syaltut dan Ali al-Sayis, Muqaranah al-Madzahib fi al-Fiqhi, Terj. Zakiy al-Kaaf, (Bandung: Pustaka Setia, 2000), p. 210.

${ }^{12}$ Louis Ma'luf, al-Munjid...p. 488.

${ }^{13}$ Abdurrahman al-Jaziri, al-Figh 'Ala al-Madzahib al-Arba'ah, Jilid 4, (Kairo: Dar al-Hadits, tth), p. 274.

${ }^{14}$ Wahbah Zuhaily, al-Fiqh al-Islami Wa Adillatuhu, jilid 9, (Damaskus, Dar al-Fikr, 1997), p. 6968.

${ }^{15}$ Sayyid Sabiq, Fiqh SUnnah, Jilid 2, Cet. 4, (Beirut: Daar al-Fikr, 1983), p. 222.

${ }^{16}$ M. Abdul Majid dan Mabruru Thalhah Syafi'ah AM, Kamus Istilah Fiqh Cet. I, (Jakarta: Pustaka Firdaus, 1994), p. 366.

${ }^{17}$ KOmpilasi Hukum Islam, Ditbinbapera Depag RI, 2000, p. 13. 
in Indonesia can be applied in Indonesian national law. National law can serve as a legal standing for the rule of national law at a more appropriate level. ${ }^{18}$

The covenant itself is etymologically interpreted as an act whereby a person or more binds himself to someone else or more. ${ }^{19}$ WJS. Poerwadarminta in the Indonesian General Dictionary gives the definition of the agreement with the consent (written or oral) made by two or more parties who promise to obey what is in the agreement. ${ }^{20}$ From these definitions, it can be concluded that the agreement is an act of agreement between a person or several persons with someone or some other person to do a certain act.

While the marriage agreement, having an understanding of the agreement made by the two bride-to-be at the time or before the marriage takes place, and each of them promises to obey what is in the agreement, authorized by the marriage registry officer. ${ }^{21}$ The marriage agreement in this case has a condition, namely the agreement made is not contrary to Islamic Shari'a or the nature of marriage. If the terms of the treaty are made contrary to the Islamic Shari'a or the nature of the marriage - whatever the treaty may be - then the treaty is invalid, there is no need to follow, while the marriage contract is valid. Thus, if the terms of the marriage agreement made are not inconsistent with Islamic law or the nature of marriage, then the law may be (legitimate), but if the condition is contrary to the Islamic Shari'a or the nature of marriage then the law of the treaty should not be (unlawful).

\section{Sighat Taklik Talak According to Islamic Law:-}

Understanding Taklik Talak itself, which is a series of divorce uttered by the husband who depends by a proving condition that may occur in the future, the authors conclude that the interests of the contents of shighat taklik talak are divided into two kinds: :

a. Shighat taklik talak in the form of the interests of the husband's right, for example the husband said: "if you go to the house of the fulan, then you are given talak". The content of the tapip takat shigat is of interest to obey the husband's command and has nothing to do with the right of the wife.

b. Shigat taklik talak in the form of the right of wife, for example the husband said to his wife: "if I do not provide you for three months, then you are given talak". The content of this second tapless takig shigat is about the right of the wife.

But the development that occurred later, especially in Indonesia, the nature of shighat taklik talak is containing the interest to maintain or guarantee the rights of the wife. According to historical records, the development of taklik talak in Indonesia began during the Islamic Mataram period, precisely at the time of Sultan Agung Hanyakrukusuma $(1630 \mathrm{AD})$. At that time the sultan issued a command or command in the form of a requirement to do taklik talak to every groom who married.

The Ulama mujtahidin other than those of the Tabi'in are Ibn Shaykh Abu Umar, Asy-Syaibaniy, Abul-Ahwash, Zaid bin Wahb, Al-Hakam, Umar ibn Abdul Aziz and Khallas bin Amr. The fatwa of their quoted fatwa, all of which stipulate the enactment of taklik talak.

Ibn Taymiyya and Ibn al-Qayyim argue that the talak mu'allaq both oath and non sworn, does not apply. Then they add, that the oath that is included in the mu'allaq talak, can be redeemed by kaffarah. In that case kaffarah is obligated as a punishment for the offense of Oaths in the name of Allah 'Azza wa Jalla. Thus Ibn Taymiyyah and Ibnul Wayyim have their own opinions far different from the opinions of jumhurul-ulama. We do not understand how two scholars who understand the secrets of shari'a law can oblige kaffarah to those who vow overthrew the mu'allaq divorce over his wife. The meaning or meaning of the vow of the oath which is obligated upon the person who violates the oath mention the name of Allah SWT is not reflected at all in kaffarah vow till mu'allaq. ${ }^{22}$

\footnotetext{
${ }^{18}$ Suryati, Reconstruction of the legal protection of civil rights for the child of adultery

based on values of justice in Indonesia, European Journal of Economics, Law and Social Sciences IIPCCL Publishing, Graz-Austria, ISSN 2519-1284, Vol. 1 No. 1 January 2017, p.. 272

${ }^{19}$ Yan Pramadya Puspa, 1977: p.248

${ }^{20}$ WJS. Poerwadarminta,1986: p.402.

${ }^{21}$ Abd. Rahman Ghazaly, Fiqh Munakahat, (Jakarta: Kencana Persada media, th), p. 119.

${ }^{22}$ Pembahasan Tuntas perihal Khilafiah, Pustaka Hidayah, H. Muh. Al-Hamid Al-Husein. P. 591
} 
In the fatwa signed by the Chairman of the MUI: Hasan Basri, Secretary of the MUI: H. A. Nazri Adlani, and Chairman of the Fatwa Commission K.H. Ibrahim Hosen, mentioned that "the pronunciation of sighat ta'liq talaq, which are historically there to protect the rights of women (wife) which at that time there is no legislation about it, now sighat ta'liq talaq pronunciation is no longer needed. For guidance toward the formation of happy family has been in the form of BP4 from the central level up to the district level. ${ }^{23}$

According to KHI, the taklik talak agreement is not a requirement in every marriage. As it can be seen in Article 46 Paragraph (3) that, "The tapless engagement agreement is not a treaty that must be held at every marriage, but once the taklik talak has been pledged irrevocably." Thus it clearly states That the agreement of taklik talak is not a necessity for every Muslim.

The taklik talak applicable in Indonesia has been arranged in such a way and to facilitate its implementation has provided the text containing the terms of writing and VAT offers only to the bride whether or not read by taklik talak. When the taklik talak is used then it will be included in the marriage book and will be signed husband as a proof that the husband's promise before the wife. If the husband is not willing to read the taklik talak in the wedding, then the taklik talak texts are then being crossed out by the officer as a sign the husband did not want to read the taklik talak. Since the reading of taklik talak is only a recommendation, then the husband was entitled not to read it in front of the bride.

Even Among the allowable, there are two opinions. Some allow absolute and some allowed it under certain conditions. The difference of ideology among those who allow it, basically lies in the form of the properties and sighat taklik talak in question. Allowing absolute permission, they permit all forms of sighat taklik, both syarthi and qasami, which are general or attributed to something. The one allowed is sighat taklik which is syarthi, and in accordance with the purpose of legal purpose syar "i. ${ }^{24}$

The juridical facts on the reasons for divorce as mentioned in Article 39 Paragraph (2) of the Marriage Law and its elucidation, as well as in Article 19 of Government Regulation Number 9 Year 1975, are not mentioned about taklik talak as reasons for divorce. The legislator considers that the divorce is based on the explanation of Article 39 Paragraph (2) of the Marriage Law jo. Article 19 of Government Regulation Number 9 Year 1975 has been sufficient, in accordance with the spirit of the law which among others adheres to the principle of exchanging divorce. So no need to be added or expanded.

In practice in the Religious Courts whether he is a contract or a reason for divorce, the judge explicitly considers it in his judgment. Should the judge sharpen efforts in qualifying the case, so the tendency so far to lead or direct the case of divorce lawsuit into the case taklik talak can be reduced.

\section{Implementation of Sighat Taklik Talak as Reasons for Divorce:-}

That Muslim jurists are interested in discussing the formulation of shitat taklik talak, the difference between them arises basically lies in the formulation of the promise of taklik talak concerned which until now still color the development of Islamic law. Ibn Hazm argues that from the two forms of taklik talak, that is taklik qasamy and taklik syarti, are both invalid and his speech has no effect whatsoever, the reason is because Allah has clearly set about the talak while taklik talak there is no guidance in al-Quran nor Al-Sunnah. Jumhur Ulama (Ulama madhhab) is of the opinion that if a person has been declared his divorce in his authority and has fulfilled his requirements in accordance with what is desired by each of them then taklik is considered valid for all forms taklik, whether taklik contains oath (qasamy) or Contains the usual terms. Because the person who did the deed did not drop his talak when the person said it, but the person who did the divorce to the fulfillment of the terms (mentioned) in his utterance. $^{25}$

${ }^{23}$ Anonim, Sighat Taklik Talak,...Mestikah di Ucapkan, http://jilbab.or.id/archives/78-sighat-taklik-talakmestikahdi-ucapkan/, date access 27 june 2017.

${ }^{24}$ Mahmoud Syaltut, Perbandingan Mazhab Dalam Masalah Fiqh, Terjemahan Ismuha, (Jakarta: Bulan Bintang, 1978), p. 218-219.

${ }^{25}$ Mahmud Syalthout, Perbandingan Madzhab... p. 227. 


\section{Reconstruction of Sighat Taklik Talak as Reasons for Divorce in Religious Courts Based on Justice Values} Fairly, the word fair is an abstract noun, derived from the word adala. In the Qur'an itself fair contains many meanings. Fair that has to do with the title of this dissertation quotationist of the word of Allah Swt ;

\section{ولثهن مثل الأى عليهن بالمعروف .}

"And women have equal rights (proportionally) with their obligations in a prosperous way." (QS al-Baqarah : 228)

The idea of fair equality is used in the sense of one thing to another. That meaning can be expressed either in qualitative or quantitative terms, which refers to the principle of abstract equations, ie, equality before the law. ${ }^{26}$

In the field of justice is known the existence of procedural justice symbolized by the Goddess of Justice, a woman who both hands holding swords and scales, with eyes closed to ensure impartial consideration and not look at who will be judged. Justice here is meant as an impartiality, thus gave birth to equality of treatment. This justice also means an impartial attitude and equality of treatment. Factors that may affecting unfair judgments are "legal substance", and "legal structure", and "legal culture". Reconstruction of merged values Distribution of property due to divorce is done on the basis of its contribution with due regard to its benefits and disadvantages. ${ }^{27}$

That the sighat taklik talak should really be a clear marriage agreement, meaning that between husband and wife have the same rights as the subject of the law of agreement. When the sighat taklik talak enters into a covenant in marriage, By adhering to the principle of equal freedom and rights in making the covenant, on the other hand by the execution of marriage in the presence of the Official Recording Officer, has spawned the rights and obligations as husband and wife as outlined by Law Number. 1 year 1974 about marriage (UUP) and the implementation regulation PP Number. 9 in 1975. In the community there may be a point of tangency between the principle of freedom of agreement with the rights and obligations set by the law. Or if the content or if the contents of the agreement is violated is there a money effort can be done by the party who feels aggrieved, can he file a civil suit or raised the breach of the marriage agreement as the reason for the divorce?

UUP does not give clear restrictions on the coverage of marriage agreements. In his explanation only mentioned, that what is meant by "agreement" in this article does not include taklik talak. The Compilation of Islamic Law (KHI) is then clarified in Article 45 which states: "The two prospective brides may enter into a marriage agreement in the form of (1) taklik talak (2) other agreements which are not contrary to Islamic law.

If what is desired with taklik talak is what is commonly pronounced after the marriage contract, then we can account for unilateral legal action (eenzijdig), in which the husband makes a promise relating to his own circumstances. When it says that a married couple has made a marriage contract, then it means they have committed themselves according to the conformity of the will.

Regarding taklik talal as the reason for divorce, the formulation of sighat taklik talak in the Marriage Act (if it is used as divorce for wife) followed by the wife's willingness to pay the iwadl (ransom) money as mentioned in the marriage certificate, the court in the name of the husband will drop the divorce One khul'i to the wife. According to the legal concept of both formal and material, there is a controversy within the KHI, the reason for divorce with taklik talak is limited to the reason, regarding the way there appears to be no explanation, while the divorce with khulu' KHI arranges it in article 148.

Khulu' is a new type or divorce procedure introduced by KHI. In fiqh, khulu 'is a divorce on the wife's initiative and for that she must give some payment (compensation) to her husband.

The rule of jurisprudence certainly can not be followed KHI perfectly because the existing legislation stipulates that the divorce must be on the grounds, should not be based on the agreement alone and must be in front of the court. So

${ }^{26}$ Achmad Ali Menguak Teori Hukum (Legal Teori) dan Teori Peradilan (Judicial Prudence), (Jakarta: Pernada Media Group, 2010), p. 244.

${ }^{27}$ Eti Mul Erowati, Reconstruction of Law of Joint Property Distribution due to Divorce to the Working Husband and Wife Based on the Value of Justice, Mediterranean Journal of Social Sciences, ISSN 2039-2117 (online) ISSN 2039-9340 (print), Vol 8 No 4 S1 July 2017 
while it is called khulu '(which is essentially a divorce deal), the wife must still state the reasons for divorce that can be proved before the court.

Based on the description above the reconstruction of sighat talak based on the value of justice as the reason for divorce in the Religious Courts based on the value of justice to realize the protection for the wife and husband in a balanced manner. While the reconstruction of the Law are :

Table 1:-Reconstruction of Law

\begin{tabular}{|c|c|c|c|}
\hline No. & Before Reconstruction & Weaknessess & Justice-value Reconstruction \\
\hline 1. & $\begin{array}{l}\text { Shigat Taklik Talak in Deed of } \\
\text { Marriage in accordance with the } \\
\text { provisions of the Minister of } \\
\text { Religious Affairs No. } 2 \text { of } 1990 \text { are } \\
\text { as follows: } \\
\text { "After the marriage ceremony, I ... } \\
\text { pledge with heart, that I will keep } \\
\text { my duty as a husband, and will be } \\
\text { my wife named ..... daughter of ... } \\
\text { with good will .. (mu'asyarah bil } \\
\text { ma'ruf) according to Islam syar'i. } \\
\text { Next I say that at any time if i: } \\
\text { 1. Leave my wife two years in a } \\
\text { row. } \\
\text { 2. Or I do not give a mandatory } \\
\text { need to her three months } \\
\text { consecutively } \\
\text { 3. Or I hurt my wife's physical } \\
\text { body, } \\
\text { Or I let (neglecting my wife for six } \\
\text { months, making my wife unhappy } \\
\text { and complain to the religious court } \\
\text { or officer who is given the right to } \\
\text { handle the complaint, and the } \\
\text { complaint is justified and accepted } \\
\text { by the court or officer, and my wife } \\
\text { paid the money of Rp .1000, - } \\
\text { (thousand rupiah) as iwadh } \\
\text { (substitute) to me, then my talaq } \\
\text { will fell to her to the court or the } \\
\text { officer I empowered that receive } \\
\text { the iwadh shall gave it for social } \\
\text { needs. }\end{array}$ & $\begin{array}{l}\text { 1. In practice , often occurs } \\
\text { where Husband is ordered } \\
\text { to Sighat Talak by the } \\
\text { marriage registrar } \\
\text { 2. Husbands does not read the } \\
\text { taklik talak and he only } \\
\text { asked by the officers to } \\
\text { sign it. } \\
\text { 3. A Promise established by } \\
\text { the Minister of Religion. } \\
\text { 4. Unilateral pledge to } \\
\text { safeguard the rights of the } \\
\text { wife, therefore if the } \\
\text { person refuses not to read } \\
\text { and sign according to the } \\
\text { Permenag no. 11 Article } 24 \\
\text { paragraph (2), the wife can } \\
\text { file a case to the Religious } \\
\text { Court in order to make } \\
\text { Sighat Taklik Talak. } \\
\text { 5. Who can use divorce } \\
\text { reasons with violation } \\
\text { Taklik Talak only wife In } \\
\text { the Religious Courts all } \\
\text { divorce by reason of } \\
\text { violating Taklik Talak, } \\
\text { verdict of Divorce is Talak } \\
\text { Khul'i }\end{array}$ & $\begin{array}{l}\text { 1. Sighat Taklik must be formulated as a } \\
\text { marriage agreement as article } 45 \text { and } \\
\text { article } 46 \text { KHI jo. Article } 11 \text { of } \\
\text { Regulation no. } 2 \text { year } 1990 \text {. So that } \\
\text { there is a balance between husband and } \\
\text { wife rights. } \\
\text { 2. Sighat Taklik Talak are not defined by } \\
\text { the minister of Religion, but determined } \\
\text { by husband and wife with balance of } \\
\text { rights and obligations of husband and } \\
\text { wife. } \\
\text { 3. Divorce by reason of Taklik Talak is not } \\
\text { only limited to wife, but also husband. } \\
\text { The Decision of the Religious Courts of } \\
\text { divorce by reason of the violation of the } \\
\text { Taklik Talak, not only with Talak Khul'i, } \\
\text { but also Talak Khul'i, Talak Bain, if the } \\
\text { wife who filed and Talak Raji ', and } \\
\text { Fasakh if the husband is the one who filed. }\end{array}$ \\
\hline 2. & $\begin{array}{l}\text { And according to Article } 11 \\
\text { paragraph (3), the agreement of the } \\
\text { Taklik Talak is considered valid if } \\
\text { the agreement is read and signed } \\
\text { by the husband after the marriage } \\
\text { ceremony is held. Paragraph (4) } \\
\text { Sighat Taklik Talak is stipulated by } \\
\text { the Minister of Religious Affairs }\end{array}$ & & \\
\hline 3. & $\begin{array}{l}\text { Divorce with violation of Sighat } \\
\text { Taklik Talak as article } 19 \text { letter (b) } \\
\text { or letter (d) jo. Article } 116 \text { KHI } \\
\text { letter (g) clearly persuades the } \\
\text { husband to violate Takal Talak }\end{array}$ & & \\
\hline 4. & $\begin{array}{l}\text { With the wife willing to pay iwadh } \\
\text { as listed in the Deed of Marriage }\end{array}$ & & \\
\hline
\end{tabular}




\section{Conclusion:-}

Based on the above description, it can be concluded that it is necessary to convey the reconstruction to institution responsible for the taklik talak in Indonesia. Sighat taklik talak becomes mafsadah when used to engineer a means to divorce by the reason of violating taklik talak. The Registrar should be more careful in noting and listing the divorce notices, as this is a formation of a new law. The judge in examining and adjudicating divorce with taklik talak not only examines and considers the violation of taklik talak, but also in creating a new law of taklik talak. Reconstruction of Sighat Taklik should be formulated as a marriage agreement as article 45 and article 46 of KHI jo. Article 11 of Regulation no. 2 year 1990. So that there is a balance between husband and wife rights and obligations.

\section{References:-}

\section{Books:-}

1. Abd. Rahman Ghazaly, Fiqh Munakahat, (Jakarta: Kencana Persada media, th).

2. Abdurrahman al-Jaziri, al-Fiqh 'Ala al-Madzahib al-Arba'ah, Jilid 4, (Kairo: Dar al-Hadits, th).

3. Achmad Ali SH. MH, Menguak Teori Hukum (Legal Teori) dan Teori Peradilan (Judicial Prudence), (Jakarta: Pernada Media Group, 2010).

4. Anonim, Sighat Taklik Talak,...Mestikah di Ucapkan, http://jilbab.or.id/archives/78-sighat-takliktalakmestikah-di-ucapkan/, diakses pada tanggal 27 juni 2017.

5. Burban Ashofa, Metode Penelitian Hukum, (Jakarta: Rineka Cipta, 2007).

6. Dedy N. Hidayat, Paradigma dan Metodologi Penelitian Sosial Empirik Klasik, (Jakarta : Departemen Ilmu Komunikasi FISIP Universitas Indonesia, 2003.

7. George Ritzer, Sosiologi Ilmu Pengetahuan Berparadigma Ganda, (Jakarta: Rajawali Press, 1992).

8. I.S. Susanto, Kriminologi, (Semarang: Fakultas Hukum Universitas Diponegoro, 1990)

9. Kamal Muchtar, Asas-asas Hukum Islam tentang Perkawinan, (Jakarta: Bulan Bintang, 1974).

10. Kompilasi Hukum Islam, Ditbinbapera Depag RI, 2000.

11. Louis Ma'luf, al-Munjid, (Beirut: Dar al-Masyriq, tth).

12. Mahmoud Syaltut, Perbandingan Mazhab Dalam Masalah Figh, Terjemahan Ismuha, (Jakarta: Bulan Bintang, 1978).

13. dan Ali al-Sayis, Muqaranah al-Madzahib fi al-Fiqhi, Terj. Zakiy al-Kaaf, (Bandung: Pustaka Setia, 2000).

14. M. Abdul Majid dan Mabruru Thalhah Syafi'ah AM, Kamus Istilah Fiqh Cet. I, (Jakarta: Pustaka Firdaus, 1994).

15. Sayyid Sabiq, Fiqh SUnnah, Jilid 2, Cet. 4, (Beirut: Daar al-Fikr, 1983).

16. _ Fiqih Sunnah, Jilid 2, Penerjemah: Nor Hasanuddin, dkk., Jakarta: Pena Pundi Aksara, 2006.

17. Sayyid Sabiq, Fiqhu al-Sunnah, Juz II, (Beirut : Dar al-Fikr).

18. Wahbah Az-Zuhaili, Fiqih Islam Wa Adillatuhu, Jilid 9, Penerjemah: Abdul Hayyie al-Kattani, dkk., Depok: Gema Insani, 2011.

19. Wahbah Zuhaily, al-Fiqh al-Islami Wa Adillatuhu, jilid 9, (Damaskus, Dar al-Fikr, 1997).

\section{Journals:-}

1. Eti Mul Erowati, Reconstruction of Law of Joint Property Distribution due to Divorce to the Working Husband and Wife Based on the Value of Justice, Mediterranean Journal of Social Sciences, ISSN 2039-2117 (online) ISSN 2039-9340 (print), Vol 8 No 4 S1

2. July 2017.

3. Suryati, Reconstruction of the legal protection of civil rights for the child of adultery based on values of justice in Indonesia, European Journal of Economics, Law and Social Sciences IIPCCL Publishing, Graz-Austria, ISSN 2519-1284, Vol. 1 No. 1 January 2017..

4. Sulaeman Abdullah, Gunarto, Akhmad Khisni, Reconstruction of courts authority in children foster rights dispute due to the differences based on the value of Islamic law justice, International Journal of Multidisciplinary Research and Development Online ISSN: 2349-4182, Print ISSN: 2349-5979, Volume 4; Issue 7; July 2017. 